Telecommunications (Net) Limited (NET) to maintain, operate and use the equipment (reported at (2013) 15 Ecc LJ 119) in order to receive answers to a number of concerns he had identified in relation to the terms of the licence agreement. The chancellor's concerns centred around the fact that NET was essentially a monopoly purchaser of the right to put telecommunications equipment in churches, such that it was not possible to assess the value of that right in relation to a particular church.

The chancellor received further evidence from the petitioners, including material of particular commercial sensitivity, which sensitivity he was asked to respect in his judgment and allow NET to comment on a draft judgment. The chancellor chose not to view such material, on the basis that his judgment and the reasons for it should be transparent. In granting the faculty sought with minor amendments to the terms of the licence, the chancellor expressed concerns about the basis upon which the size of the licence fee was reached. The licence fee was a fixed standard fee dependent upon the size of the conurbation within which the church was located, with no scope for adjustment to take account of the value of a particular site. Nevertheless, the fact that there were five-yearly upward-only licence fee reviews incorporated in the terms of the licence, which might themselves be used to re-negotiate the licence fee to reflect the value of a particular site, meant that what was proposed was not unreasonable. [RA]

doi:10.1017/So956618X13000070

\title{
KS v TS
}

Dunfermline Sheriff Court: Sheriff Ian D Dunbar, 1 November 2012 Divorce - Muslim/Christian couple - children's religious upbringing

The parents, a woman from a Brethren family who had ceased to practise when she turned eighteen and an Egyptian Muslim man, had married in 2001. They had twin boys (circumcised with the mother's written consent) and a girl. After the marriage breakdown in 2010 the mother started attending her parish church and from the beginning of 2012 took the children to church when they were staying with her, though she only gave them food that was halal. Equally, the father had become a more observant Muslim and had started taking the children with him to the mosque. The father regarded raising his children as Muslims as a religious obligation and, as part of the proceedings, sought an order to that effect, believing that attending the parish church as well as the mosque would merely confuse them. The mother believed that the children should be brought up to understand both 
religions. She was content that their father should teach them about Islam, pray with them and take them to the mosque and said that she would not intentionally feed them non-halal meat; however, she told the sheriff that she would find it difficult to comply with an order requiring their upbringing as Muslims. Sheriff Dunbar agreed and concluded that a specific issue order that the children be brought up as Muslims would not be in their best interests; but he accepted the mother's undertakings in relation to their participation in Islam when staying with their father. [Frank Cranmer]

doi:10.1017/So956618X13000082

\section{Re St Mary the Blessed Virgin, Eastry \\ Commissary Court of Canterbury: Ellis Com Gen, 1 November 2012 Confirmatory faculty - lead theft - replacement material}

Following the theft of a quantity of roof lead from a Grade I listed church, the parochial church council (PCC) contracted with a builder to remove and dispose of the remaining roof lead and to re-cover the whole roof in an artificial, non-metal roofing material known as 'Ubiflex', at a cost of approximately $£ 90,000$. The remaining lead was sold to a recycling company. The works, and sale, were undertaken without the authority of a faculty. The archdeacon considered whether to apply for a restoration order but did not do so provided that a petition for a confirmatory faculty was issued within a specified period. A petition was submitted, accompanied by statements of significance and need. The Commissary General gave directions for an expert report on the state of the roof and the adequacy of the re-roofing works from an architect approved by the Diocesan Advisory Committee (DAC). She also directed consultation with English Heritage, the DAC, the local planning authority and relevant amenity societies, and added the building contractor as a party to the proceedings. The architect reported that the removal of the lead had resulted in a loss of significance of the building, that the replacement roof covering was likely to be effective in the short to medium term (10-15 years) and that the change in material had had a minimal effect on the aesthetic qualities of the church. He recommended that the covering be regarded as a temporary measure that should be replaced by lead or other suitable metal when the risk of theft had reduced. In the meantime, it should be inspected on an annual basis as to its effectiveness. The bodies who were consulted all disapproved of the decision to use Ubiflex and of the removal of the remaining lead. The DAC advised that Ubiflex was not 